\title{
Facilitating Aligned Co-Decisions for More Sustainable Food Value Chains
}

\author{
Gaëlle Petit ${ }^{1,2, * \mathbb{D}}$, Gwenola Yannou-Le Bris ${ }^{3}\left(\mathbb{D}\right.$, Claudia Eckert $^{4}$ and Yan Liu ${ }^{5}$ \\ 1 Oniris, LEMNA, Université de Nantes, 44035 Nantes, France \\ 2 Institut de Recherche en Sciences et Techniques de la Ville, CNRS, 44321 Nantes, France \\ 3 Université Paris-Saclay, INRAE, AgroParisTech, UMR SayFood, 91300 Massy, France; \\ gwenola.yannou-lebris@agroparistech.fr \\ 4 School of Engineering and Innovation, The Open University, Milton Keynes MK7 6AA, UK; \\ claudia.eckert@open.ac.uk \\ 5 School of Computer Science and Technology, Changchun University of Science and Technology, \\ Changchun 130022, China; amy.yanliu@outlook.com \\ * Correspondence: gaelle.petit@oniris-nantes.fr
}

check for updates

Citation: Petit, G.; Yannou-Le Bris, G.; Eckert, C.; Liu, Y. Facilitating Aligned Co-Decisions for More Sustainable Food Value Chains. Sustainability 2021, 13, 6551. https://doi.org/10.3390/su13126551

Academic Editor: Peter J. Batt

Received: 27 April 2021

Accepted: 3 June 2021

Published: 8 June 2021

Publisher's Note: MDPI stays neutral with regard to jurisdictional claims in published maps and institutional affiliations.

Copyright: (c) 2021 by the authors. Licensee MDPI, Basel, Switzerland. This article is an open access article distributed under the terms and conditions of the Creative Commons Attribution (CC BY) license (https:// creativecommons.org/licenses/by/ $4.0 /)$.

\begin{abstract}
The transition of existing food value chains towards greater sustainability is a societal imperative and a potential competitive factor. To succeed, some actors in the chains define new practices to establish common sustainability goals. To date, there is little evidence that the visions and values of the various actors in the chains have been leading to common solutions. This work explores the impact of collaboration on the value chain actors' ability to jointly decide strategies for redesigning their activities. It reports on an empirical approach, which elicits the values and priorities of different stakeholders. The case takes place in the context of a value chain of the production/processing/sale of pork products. This value chain involves two French production-processing and redistribution cooperatives. Stakeholders were questioned about their prioritization of sustainability issues and these weights were applied to evaluate 12 animal feed solutions that vary in terms of the composition and geographical origin of rations, and the means and locations of their production. The results show that despite several years of cooperation, the objectives of the upstream and downstream actors remain different. The objectives of the upstream actors are driven by the economic difficulties of production and those of the downstream actors by the multiplicity of consumer demands and cost control objectives. In a reversal of the current practice marked by the economic difficulties of the actors upstream of the chain, an integrated culture could be led by bottom-up approaches to create a shared vision. Public policy would be then essential in regulating the sharing of value among actors; and in promoting chain models that help the required investments.
\end{abstract}

Keywords: sustainability; value chain; food; co-decision; collaboration; cooperation; pork

\section{Introduction}

The environmental, economic and social sustainability of food value chains (FVCs) is an increasingly pressing challenge for all. The Food and Agriculture Organization of the United Nations (FAO) defines sustainable food chains or systems as "the set of farms and enterprises and their successive coordinated value-adding activities that produce particular agricultural raw materials and process them into particular food products that are sold to final consumers and disposed of after use, in a way that is profitable across the board, has broad benefits for society and does not deplete natural resources permanently" [1]. The development of such sustainable food systems must address the serious environmental consequences of production [2], particularly in the case of meat [3]. In addition, the system must also meet growing consumer demand [4]. Therefore, the capacity of organizations to propose real solutions to these challenges is a means of strengthening their competitiveness [5-9]. This requires strategic and operational alignment within food value 
chains [10-12]. However, how these agro-industrial value chains, which shape a large part of current food systems in developed countries, are transformed, remains poorly documented. This paper explores the impact of collaborations on the ability of value chain actors to jointly decide strategies for redesigning their activities, by focusing more specifically on their shared values. The main goal is to investigate whether a strong cooperation between two actors makes it possible to agree on solutions to improve their sustainability practices. The case study investigates two French cooperatives (agricultural and distribution), who are contractually committed to the development of a more sustainable food value chain for pork products. The cooperation between the producers and the distributor aims to develop more environmentally, economically and socially satisfactory solutions than what is currently offered by this industrial sector in France. However, it is possible that a shared passion for sustainability does not necessarily imply that the actors prioritize the same values. This is what this article will question.

Traditionally, these chains are what sociotechnical transition theory calls dominant regimes [13], where major brands or retailers drive other actors to adopt practices and processes that give the food products sustainable characteristics [14]. However, more collaborative approaches are emerging from new partnerships within value chains (VCs) [15-17]. These collaborative approaches are at the heart of the codesign of work means and practices as defined in the concept of coupled innovation [18]. This codesign can be synchronous, where innovations are simultaneously implemented in a value chain; or asynchronous, where an innovation in one part of the chain leads to a subsequent transformation in another part of this chain [19]. While the topic of FVC governance has received much attention [20-24], numerous studies have been carried out in the United States and Europe on alternative food networks, which are regionally based on agricultural actors [25]. However, little work has been done on the role of codesign in the sustainable transition of existing food value chains with dominant regimes.

Sustainability assessment is a complex problem [26-28] which involves multiple criteria (including economic, social and environmental criteria) being pulled in opposite directions by different actors $[29,30]$. This multicriteria assessment, which is challenging within an organization, becomes a headache within a group of stakeholders with interests that are, if not systematically opposing, at least difficult to combine. The case includes companies deciding to act together to improve the sustainability of their activities and products. This makes them an ideal case study for analyzing the influences of their desire to contribute a sustainable food system and their personal interests on making decisions about redesigning their value chain.

Section 2 presents a review of the literature and examines approaches that facilitate joint and aligned decision-making within value chains. Section 3 describes the context of the case study and offers a framework for the decision-making by value chain actors. Section 4 reports on the results and explains how, despite very different weightings of the evaluation criteria by the stakeholders interviewed, one scenario was systematically evaluated as the best performing option. Section 5 examines this unanimous best-performing scenario, and Section 6 draws conclusions.

\section{Strategic Decision-Making in Food Value Chains}

A food value chain (VC) is made up of all stakeholders involved in the coordinated production and value addition activities that are necessary to produce food [31]. VCs form interorganizational networks [32] involving producers, processors, distributors, consumers and civil society stakeholders [33]. The concept of value chain also highlights the role of the relationships that link these different actors to each other and to their stakeholders [34]. It is the optimization of the management of these interfaces, as well as the optimization of the coherence of strategic activities that leads to a maximization of value creation. In our work we consider that the value created is not only economic but also environmental, social and societal. The value chains are part of different food systems (segmenting in particular the short and long circuits), and of which Rastoin et al. [35] offer the following definition: 
(i) a sequence of activities from design to realization (structure and input/output flows);

(ii) a geographical and economic space, estimated through the location and concentration of activities (market shares) in relation to international trade;

(iii) an institutional context (public policies, regulations, conventions and public or private standards); and

(iv) a system of governance (power relations that determine the allocation of human, financial and material resources within global value chains).

The food system, which constitutes a model of food production and distribution for economists, is seen here as a product-based value chain rather than a sector-based approach.

In developed countries, the development of agribusiness has led to the predominance of "captive value chain", where producers are largely locked into the main buyers in the distribution sector. Gereffi et al. [36] argue that the position and power of distributors are directly linked to their direct relations with consumers, who (1) provide an outlet for the producers [37] and (2) are more in tune with consumer expectations than many producers [38-43]. Research on power relations between organizations has shown that the nature of the relations (coercive, legitimate, expert, referent, and rewarding) between actors affects the commitment of upstream actors and therefore the system itself [44]. While some producers take advantage of an association with a distributor to strengthen their position in the market, many suffer economically from this situation of dependence. Small producers and processors are in particularly difficult positions when they are confronted with major actors such as national distributors [45].

However, strong dominance of distributors hinders overall improvements in the sustainable performance of value chains and the products and services they provide, because different stakeholders across the product life cycle must cooperate to exchange information and knowledge [46]. Dominance is likely to create information asymmetries between upstream and downstream stakeholders. Collaboration and cooperation can reduce this asymmetry and give agricultural producers a capacity for action. In nonintegrated chains, the ability of upstream actors to invest is often linked to the level of economic risk, which is correlated to the length of association between producer and distributor. Sustainable transitions require cooperation mechanisms between value chain actors, which in turn transform the specific processes in each company [47]. Voluntary commitment of actors changes the nature of their relationships and decision-making processes [48]. Typically, product specifications that frame sales contracts are associated with price negotiation. The governance of VCs is dependent on the competitiveness of the sector [49]. The competitiveness of the agri-food sector leads to a need for product differentiation that can be created through signs of sustainable quality. Collaborative ecosystems can enable sustainable quality to be coproduced, increased and shared, i.e., not limited to consumer satisfaction alone [50]. This collaboration is manifested in the strategic decisions that need to be made to design or redesign the value chain [51]. However, the issue of facilitating joint decision-making effectively remains to be addressed [52].

The case study food value chain has long standing contractual arrangements and a stated commitment to sustainability by all parties. The value chain has developed a label and new products with increasing market shares in a difficult sector in the French market. We therefore expect to see common sustainability objectives.

\section{The Case Study Context and Methodology}

This section sets the context of the pork supply chain and introduces the actors. It then outlines the approach taken to answer our research questions.

\subsection{The Case Study}

In food value chains, pork value chains are the most cited examples of high integration, besides poultry [53]. In France cases of complete integration of food value chains remain rare in all sectors of food production. The case study focuses on the animal feed stage, which 
is a strong contributor to the impacts of these types of value chains. According to data from the French Ministry of Agriculture and Food, since 2007, it has accounted for approximately $80 \%$ of the total production costs (https: / / agriculture.gouv.fr/indices-filiere-porcine, accessed on 7 June 2021). Animal feed contributes $50-85 \%$ of the impact on climate change, $70-96 \%$ of total energy consumption, $64-97 \%$ of the impact on eutrophication and almost all of the impact on land use $[54,55]$ in the agricultural production stage. Feed can be produced and formulated in a variety of ways, and data that allow the assessment of environmental, economic and social impacts are available [56]. The formulas used for the study are presented in Appendix A.

In France, the animal production sector is mainly made up of cooperatives. In this study, two cooperatives are involved. The first is an agricultural cooperative whose activities range from the production of piglets to the cutting and preparation of meat. The second is a cooperative of franchised distributors with a national presence. The value chain consists of seven stages shown in Figure 1. The first four are included in the scope of the agricultural cooperative. The last three are within the scope of the distribution cooperative. The agricultural cooperative therefore includes the following activities:

- The animal feed suppliers manufacture and sell animal feed to farmers. The feed sold may be partial rations, which supplement farm production or complete rations composed of cereals, proteins and mineral supplements.

- The breeders breed and/or buy (from the cooperative) and raise piglets until they are taken to the slaughterhouse at an average age of 6 months.

- The slaughterhouses receive and slaughter the animals. They also carry out quality control inspections of the carcasses.

- The processors cut the carcasses and develop a diverse range of fresh or cured meat products.

- The animal feed supplier, the breeders, the slaughterhouse and the processor are part of the agricultural cooperative (\#1)

- The distribution cooperative manages the platform (\#2 stocker) that oversees the storage and retail (\#3 retailer) of the final production through the stores to the consumer.

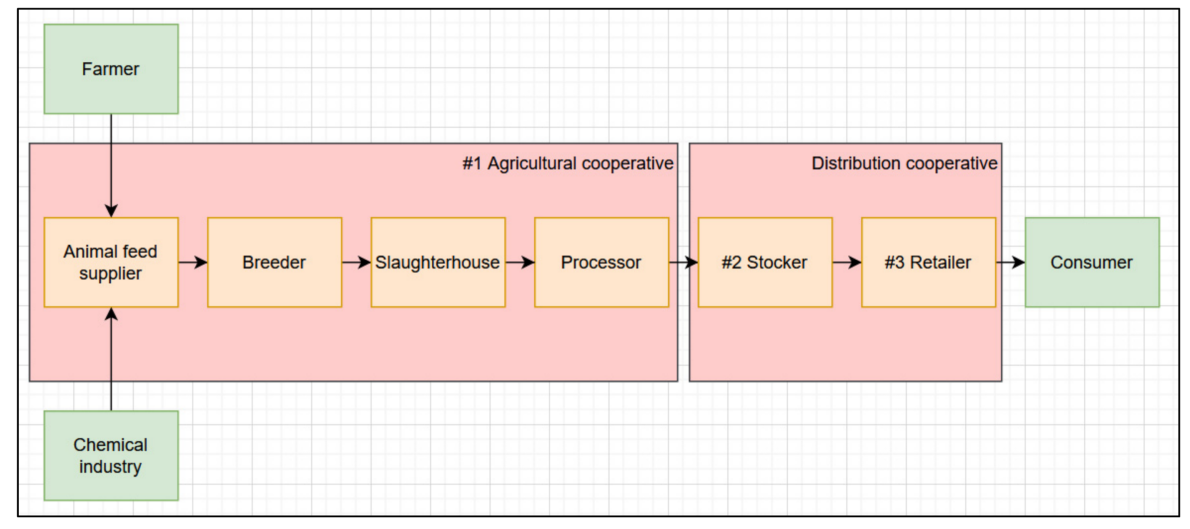

Figure 1. Schematic depiction of the Food Value Chain.

The chosen value chain is built around an agreement between the actors on a range of cobranded products. Certified by a third party, this agreement covers the general requirements of the means to be used for production, the performance to be achieved and the economic framework for defining trading volumes and prices. This framework agreement is therefore not limited to sustainability, and leaves farmers free to use their own resources for breeding, depending on whether their farm also includes an agricultural crop production activity. Moreover, the farmers who take part in this value chain do so on a voluntary basis. The quality criteria and the required level of performance for products already marketed have been jointly defined by the two organizations. The choices regarding these criteria have led to changes in production practices. In return, the stockers 
and retailers support the development of the sector by helping, for example, to add value to the low cuts of pork that could not be marketed directly in the new brand's product portfolio.

\subsection{Methodology}

This article is the result of the collaboration between two doctoral works.

The first author's research concerns sustainable agri-food value chain, which need to establish and deploy a coherent sustainability strategy for its various stakeholders. They also need to succeed in communicating their efforts to the public and to consumers, whose demand for more sustainable products is growing. Other interests lie in the sustainable performance of the chain, as well as in standardized and interoperable management tools to represent and monitor it. A metric for assessing the sustainable performance of food value chains was built through this work. These metrics were used to evaluate different solutions for redesigning the value chain, in particular through the implementation of closed energy loops based on the implementation of a co-fed methanizer supplied by the different actors of the pork value chain (Petit et al., 2017).

The fourth author's work is concerned with improving the performance of an economic actor through the selection of suitable suppliers according to preferences reflecting the actor's strategies [57]. She developed a supplier selection and evaluation tool [58], which combines expert assessment and facts in verbal and numerical form and uses triangular fuzzy numbers (TEN), AHP (Analytic Hierarchy Process) and TOPSIS (Technique for Order Preference by Similarity to Ideal Solution).This fuzzy decision-making tool was used to assess the performance of suppliers according to metrics for evaluating the sustainable performance of food value chains, established in the work of the first author. These metrics take into account economic, environmental and social aspects (three pillars) and focus on areas of critical concern in a food value chain. The triple bottom line diagram can be traced back to Barbier [59], but the conceptualization of three pillars predates it. The concept arose from a gradual emergence of various critiques in the early academic literature of the economic status quo from both a social and ecological perspective as well as and the need to reconcile economic growth with addressing sustainability (Purvis et al., 2019). Following this terminology, the metric is referred to as pillars and represented by columns in the results of this article.

The empirical approach for studying the role of codesign in the sustainable transition of a food value chain followed four steps (see Figure 2).

- Step 1: Construction of animal feed alternatives: different feed configuration scenarios

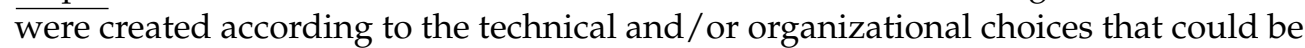
adopted. They were verified with an expert and take out of 4 .

- $\quad$ Step 2: The performance of these scenarios was evaluated from environmental, eco$\overline{\text { nomic }}$ and social points of view according to the indicators defined in Petit et al. [60]. These indicators were established on the basis of 17 interviews with actors in the value chain and some of their stakeholders. These interviews were also supplemented by a literature review, as done by Öberg [61], and by reading newspaper articles, press releases and through e-mail exchanges with some of the interviewees. Such an approach allows a detailed analysis of the practices and strategic objectives of the different actors [62] and triangulates information.

- $\quad$ Step 3: The set of indicators created in Step 2 were used to determine the sustainable performance levels (economic, social and environmental) of the different feed alternatives defined in Step 1. The unit of analysis was the production over one year of a medium-sized pig farm of 200 sows, which were then processed and distributed to consumers in the form of standardized fresh sausages. For the study, environmental indicators were calculated using a specific life-cycle analysis software (Simapro). To quantify the physical flows, secondary data was taken from a study carried out by a French Chamber of Agriculture [63] (Annexes). The data for the economic and social 
indicators were extracted from the literature and adapted to different feed supply scenarios [64].

- $\quad$ Step 4: Four stakeholders were interviewed (\# numbers used in Figure 1) with a semi-structured questionnaire:

- $\quad \# 1$ a representative of the agricultural cooperative (project leader);

- \#2 a stock keeper, who was responsible for a logistic platform (from the project leader's distribution cooperative); and

- $\quad$ \#3 (1) and (2) two retail store managers (from the project leader's distribution cooperative).

- $\quad$ Step 4a: To determine the similarities or differences in the views on sustainability objectives of the different actors involved, we asked them to establish their priorities. They worked in pairs and compared all criterion two-bytwo to determine the relative importance of the indicators for each cooperative's sustainability strategy. The four actors where asked to carry out the following assessments:

- (1) The importance attached to each pillar.

- (2) The importance of each criterion in each pillar/column.

The ranking scale in both steps was from very high importance (weight value of 1) to very low importance (weight value of 5).

- Step 4b: To establish the impact of these points of view on the ranking, we then

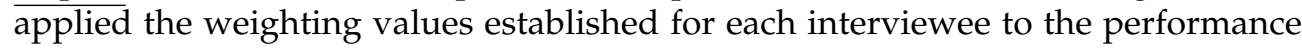
values calculated in step 3 . This operation makes it possible to rank the solutions according to two inputs: their intrinsic performance and the importance given to the different criteria by each individual evaluator.

Figure 2 summarizes these different steps.

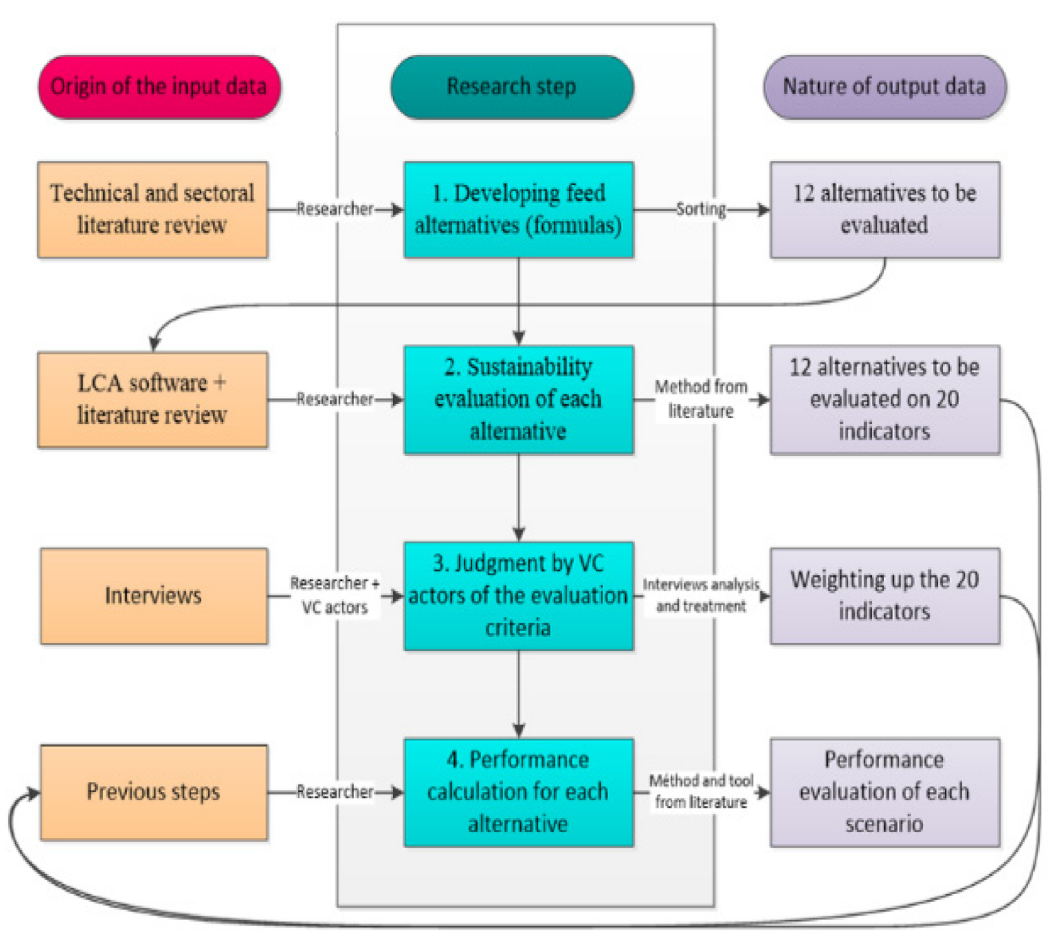

Figure 2. Overall study approach.

\section{Results}

\subsection{Comparative Alternative Solutions}

In general, pigs need a source of energy, a source of protein (or nitrogen) and a mineral source with variations depending on whether they are raised for their meat or for 
reproduction; and physiological stage (nursery, fattener, or finisher). Energy is provided by cereals (usually maize, wheat or barley), oils or tubers. Nitrogen can be supplied by the inclusion of oilseed cake or by feeding milk powder, a byproduct. Minerals (calcium carbonate, phosphates, salt, etc.) are supplemented, and additional amino acids may have to be purchased from a specific supplier. Many raw materials are mixed sources (energy and protein). Figure 3 illustrates the 12 different scenarios developed for this study, which were verified by an animal nutrition expert. The parameters considered for their definition include the ingredients, the geographical origin (soy comes from Brazil or the USA) of these ingredients and the storage facility used to create the feed mixes (indicated in the boxes). The scenarios are modeled using the responses of the interviewees and a bibliographic review to complete the data.

Legend. A mixed box corresponds to a farmer's own product supplementation by bought-in feed.

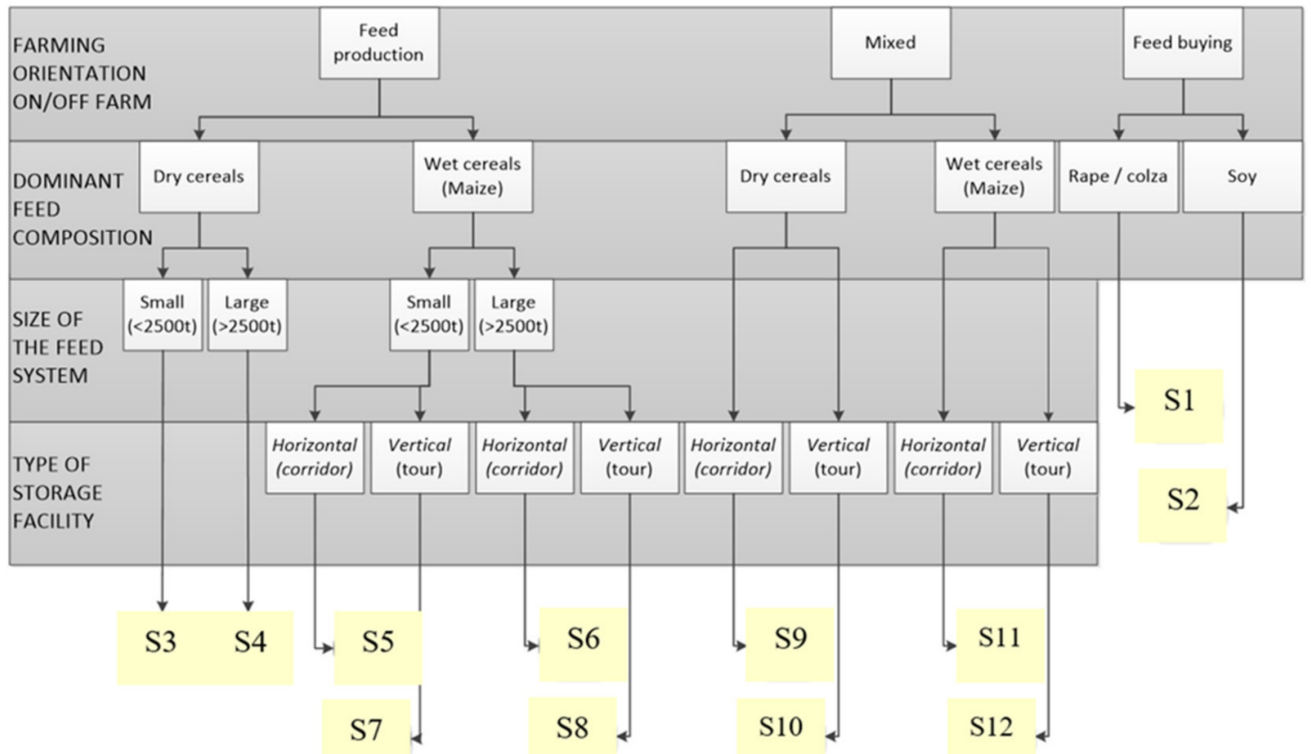

Figure 3. Main characteristics of animal feed alternatives compared in this study.

\subsection{Weights of the Sustainability Criteria Provided by the Various Stakeholders}

The weightings of the values are given directly by the interviewed actors, questioned on the importance of the indicators two by two. Then, the software tool developed by Liu et al. [57] gives a weighted score for each indicator. Table 1 gives a weight value for each indicator, which was calculated by the tool based on the comparative judgments given by respondents using Analytic Hierarchy Process (AHP) [65]. The weights were aggregated by cooperative: DM1 for the upstream agricultural cooperative and DM2 for the downstream agricultural cooperative. Three weights were aggregated for one cooperative and one from the other. The color code indicates a high weight as a light blue color (from 0.07 to 0.3 ), a low weight as a dark blue color (from 0 to 0.01 ) and an intermediate weight as a medium blue color. The first three lines indicate the weights of the pillars together, and the following lines inside the pillars indicate the weights of the impact indicators. The first line of each pillar (environmental, economic, and social) where no indicator name appears corresponds to the weight given to each pillar, comparatively between them and according to stakeholders' judgments, respectively. 
Table 1. Relative weight of each pillar and indicator according to stakeholders' judgments.

\begin{tabular}{|c|c|c|c|c|}
\hline Pillar & Indicator & Unity & DM1 & DM2 \\
\hline & Environmental & & 0.093088 & 0.333333 \\
\hline & Freshw. eutroph. & $\mathrm{kg} \mathrm{SO} 2 \mathrm{eq}$ & 0.003217 & 0.072038 \\
\hline & Terrestrial acidif. & $\mathrm{kg} \mathrm{SO} 2 \mathrm{eq}$ & 0.003217 & 0.009036 \\
\hline & Human toxicity & $\mathrm{kg} 1.4-\mathrm{DB}$ eq & 0.022061 & 0.009036 \\
\hline & Fossil-fuel depletion & $\mathrm{kg}$ oil eq & 0.008865 & 0.009036 \\
\hline & Water depletion & $\mathrm{m}^{3}$ & 0.008865 & 0.009036 \\
\hline & Climate change & $\mathrm{kg} \mathrm{CO} 2 \mathrm{eq}$ & 0.031562 & 0.009036 \\
\hline & Land occupation & $\mathrm{m} 2 \mathrm{a}$ & 0.008865 & 0.072038 \\
\hline & Freshwater ecotox. & kg 1.4-DB eq & 0.003217 & 0.072038 \\
\hline & Marine ecotox. & kg 1.4-DB eq & 0.003217 & 0.072038 \\
\hline & Economic & & 0.813825 & 0.333333 \\
\hline & Invest. short-term & $€ /$ ton & 0.04313 & 0.095192 \\
\hline & Invest. mid-term & $€ /$ ton & 0.04313 & 0.011939 \\
\hline & Invest. long-term & $€ /$ ton & 0.04313 & 0.011939 \\
\hline & Feed manuf. cost & $€ /$ ton & 0.213768 & 0.095192 \\
\hline & Total feed cost & $€ /$ ton & 0.213768 & 0.011939 \\
\hline & Waste & $\%$ & 0.213768 & 0.011939 \\
\hline & Added labor cost & $€ / \mathrm{kg}$ & 0.04313 & 0.095192 \\
\hline & Social & & 0.093088 & 0.333333 \\
\hline & Sup. work hours & h/day & 0.067664 & 0.083333 \\
\hline & Biodiv. varieties & \#/formula & 0.008475 & 0.083333 \\
\hline & Biodiv. species & \#/formula & 0.008475 & 0.083333 \\
\hline & Localness (100-) & $\% /$ formula & 0.008475 & 0.083333 \\
\hline
\end{tabular}

Table 1 reflects a very significant perception gap between the upstream and downstream parts of the value chain with respect to the priorities of goals in the chain. The upstream actors have to assume the direct consequences, therefore, the economic factors of investment costs and particularly operating costs are central. This economic issue "crushes" the other dimensions since upstream actors have shifted 0.82 points of their weighting to economic issues, compared to only 0.09 for both environmental and social issues. In environmental terms, two issues appear: the contribution to the climate and the impact of their activities on human health. Both subjects are highly-publicized in the general media and the farmers are sometimes called upon to provide solutions to these issues.

The priorities of the downstream actors were evenly distributed across the three impact categories with 0.33 points on environmental, economic and social. The economic dimension was mainly considered in terms of the immediate impact on production costs. With regard to environmental impacts, the impact on the climate, which was very high in the context of food systems, is not prioritized here. On the other hand, indicators such as land use and water pollution, which are sensitive subjects for the populations living near the installations, were highlighted as priority themes. Finally, for these actors, all societal issues, which are open to public debate, were considered to be major.

\subsection{Ranking of Solutions According to Weightings}

The tool finally gives the final unique scores for each scenario as well as a performance level. In step 3, the score columns were calculated using TOPSIS to evaluate the scenarios 
according to the judgments of the actors using triangular fuzzy numbers as the inputs. TOPSIS [66] is based on the idea that the chosen alternative should be closest to the best possible solution for and farthest from the worst performance in each criterion. As the decision is often carried out collectively, the tool supports synthesizing the judgements of multiple value chain actors. The overall performance of a supplier is the result of the weights multiplied by the scores. The performance profile of scenarios is established according to their strengths, weaknesses, opportunities and threats using SWOT matrix analysis. A SWOT matrix analyzes the level of a business's preparedness for these four aspects by identifying the internal and external factors that influence the achievement of a business goal [67]. Here, the SWOT concept is used to translate the performance of the different scenarios analyzed. Two dimensions enter into the calculation: the weight of the criterion, indicating its importance for the actor, and the score of the scenario against the worst and ideal solutions.

Thus, the score interval $[0,1]$ is divided into three ranges and the performance of a supplier is defined as follows:

- $\quad$ "Excellent" for the interval [1, 0.67)

- $\quad$ "Acceptable" for the interval [0.67, 0.33]

- $\quad$ "Poor" for the interval [0, 0.33)

Legend. There are three performance levels possible for each alternative:

- P-Poor performance (first third, score from 0 to 0.33 ), which is in light blue in the table.

- A-Acceptable performance (second third, score from 0.33 to 0.66 ) in medium blue in the table.

- $\quad$ E-Excellent performance (last third, score from 0.66 to 1) in dark blue in the table.

Table 2 shows that despite different weights assigned by upstream and downstream actors, the food solutions 1 and 2 purchased from the cooperative and which do not require storage facilities, systematically appear as the best solutions. However, the individual scores on the social dimensions were not high according to the criteria used in this study. These scenarios offer an interesting economic solution in the short term, given the cost regulation of raw materials that the cooperative manages to maintain at this stage (although these materials have been subject to the price volatility for the last ten years). The costs were lower than local production, because the rapeseed and soybean used came from areas with low labor costs and the cooperative enabled economies of scale. These solutions had a high position, because of the low emphasis on the climate in the weights given by the actors.

Table 2. Relative ranking of the performances of each alternative according to the importance given to each indicator by the actors (\#) interviewed.

\begin{tabular}{|c|c|c|c|c|c|c|c|c|c|c|c|c|}
\hline & \multicolumn{3}{|c|}{$\# 1$} & \multicolumn{3}{|c|}{$\# 2$} & \multicolumn{3}{|c|}{$\# 3(1)$} & \multicolumn{3}{|c|}{$\# 3(2)$} \\
\hline & Score & Rank & Perf & Score & Rank & Perf & Score & Rank & Perf & Score & Rank & Perf \\
\hline S1 & 0.957 & 1 & $\mathrm{E}$ & 0.697 & 1 & $\mathrm{E}$ & 0.797 & 1 & $\mathrm{E}$ & 0.616 & 1 & A \\
\hline S2 & 0.814 & 2 & $\mathrm{E}$ & 0.662 & 2 & $\mathrm{E}$ & 0.792 & 2 & $\mathrm{E}$ & 0.604 & 2 & A \\
\hline S3 & 0.398 & 5 & A & 0.448 & 6 & A & 0.432 & 3 & A & 0.475 & 5 & A \\
\hline S4 & 0.395 & 6 & A & 0.414 & 8 & A & 0.392 & 5 & A & 0.459 & 6 & A \\
\hline S5 & 0.24 & 11 & $\mathrm{P}$ & 0.404 & 9 & $\mathrm{~A}$ & 0.255 & 10 & $\mathrm{P}$ & 0.313 & 11 & $\mathrm{P}$ \\
\hline S6 & 0.236 & 12 & $\mathrm{P}$ & 0.364 & 12 & A & 0.218 & 12 & $\mathrm{P}$ & 0.298 & 12 & $\mathrm{P}$ \\
\hline S7 & 0.257 & 9 & $\mathrm{P}$ & 0.477 & 3 & A & 0.365 & 6 & A & 0.378 & 8 & A \\
\hline S8 & 0.254 & 10 & $\mathrm{P}$ & 0.432 & 7 & A & 0.332 & 8 & A & 0.364 & 9 & A \\
\hline S9 & 0.456 & 4 & A & 0.381 & 10 & A & 0.316 & 9 & $\mathrm{P}$ & 0.516 & 4 & A \\
\hline S10 & 0.471 & 3 & A & 0.468 & 4 & A & 0.43 & 4 & A & 0.603 & 3 & A \\
\hline S11 & 0.334 & 8 & A & 0.381 & 11 & A & 0.239 & 11 & $\mathrm{P}$ & 0.34 & 10 & A \\
\hline S12 & 0.347 & 7 & A & 0.461 & 5 & A & 0.363 & 7 & A & 0.415 & 7 & A \\
\hline
\end{tabular}




\section{Discussion}

\subsection{Views from Different Actors}

The assessments of the different solutions were calculated and therefore do not reflect a conscious by each actor. They were derived from a combination of the performance of the solutions and the priorities established by the stakeholders. Apart from a codesign approach, the mechanisms that govern the selection of an animal feed solution are generally linked to nutritional criteria allowing the pigs to gain as much weight as possible in the shortest possible time on the one hand, and economic criteria on the other hand.

The weights set by the upstream and downstream actors were very clearly different. It is important to note that the breeders involved in this process within the cooperative are volunteers. As a result, some of the breeders in the cooperative are not involved in such an approach, and those who are involved in this initiative indicate their willingness to change their practices. The upstream actors were subject to strong economic pressure and choose solutions that were less expensive in the short term. The purchase of animal feed, regardless of whether the formulation is soybean or rapeseed-based, is a suitable alternative because (1) no individual investment is required and (2) relieves farmers of the need to find and negotiate raw materials or to manage multicrop farms. On the other hand, these farmers lose their autonomy. The actual individual choices made by farmers were therefore highly dependent on the vision that each farmer has of his occupation or vocation. The economic pressure imposed on producers is blocking the medium- and long-term perspectives of the production and work choices. This observation also applies to the societal impacts of these choices in the long term.

The downstream actor, in line with the expectations of consumers as direct clients [4], gave equivalent weights to the different categories, which showed significant recognition of social criteria. Because of direct contact with customers, it can be assumed that the actors in the downstream part of the value chain are much more sensitive to customer expectations than those upstream. However, there is a growing demand from consumers for access to less impactful consumption. In 2019, 80\% of French people declared that they wished to reduce the impacts of their consumption on the environment [68]. To provide solutions that meet these expectations, downstream actors are striving to simultaneously improve the various sustainability features of their offers and maintain their activity. Moreover, the fundamentally different cultures of the two cooperatives do not allow them to adopt the same ranking of indicators. The agricultural cooperative has selected indicators that reflect its work on biodiversity and landscape conservation, i.e., those that concern the upstream agricultural sector. The distribution cooperative focuses instead on logistics, giving priority to the management of the transport fleet and greenhouse gas or particle emissions. Each cooperative remains focused on its own interests and objectives: the agricultural cooperative on upstream issues and the distribution cooperative on downstream issues. Here, experience shows that, although the two cooperatives work together to improve the sustainability of their products and practices, each actor has a detailed knowledge of only their own practices and the degrees of freedom they have. This leads them to use different performance criteria.

This discrepancy between upstream and downstream actors also appeared during the interviews with the actors of the value chain. These discrepancies between upstream and downstream are frequent in agri-food chains [69]. When asked about how to increase sustainability of production, farmers indicated that they were not in a position to clearly establish a direction. Solutions that work for all actors can be developed collectively. However, upstream actors cannot put these solutions in place alone. They must then be subsidized by public authorities or failing that by the downstream actors in value chains. This is sometimes possible, if the farms also contribute for example to the protection of the landscape and thus benefit from national or regional financial aid (e.g., through support from the French water agency when the farming methods adopted make it possible to reduce chemical inputs). Ultimately the customer must pay a higher price for more sustainable products. Upstream agricultural actors, particularly in financial difficulty, must, 
therefore, be assisted in the identification, evaluation and implementation of solutions to improve sustainability, but also in the concrete financing of these solutions, by public and/or private partners.

In summary, despite a common willingness of the upstream and downstream actors in the value chain to conduct their activities with constant improvements in their contributions to greater sustainability, their approaches to this objective remain divergent in the case studied.

\subsection{Knowledge Sharing and Strategic Alignment}

Despite three years of collaboration between the two cooperatives, the case study reveals that the sharing of knowledge and values was insufficient at this stage to allow for an alignment of their objectives. Contrary to Gölgeci et al. [70], which shows that environmental collaboration as a means of using social capital and relational capacity makes it possible to achieve an environmental performance superior to what a company could achieve alone. However, the collaboration in this study should extend to means complementary to social capital and relational capacity, through environmental agreements. This result can be seen in the differences in the hierarchical ranking of the impacts assigned by the upstream and downstream actors of the value chain and in the fact that the evaluations carried out did not give rise to a discussion of these results, which could have been a first step towards a common definition of objectives. As we pointed out earlier, the highlighted solutions were calculated from the weight given by the stakeholders to the different performances of the solutions. The intrinsic merit of each of these solutions should have been discussed jointly by the upstream and downstream agricultural stakeholders. The quantitative evaluation of the performance of a value chain seems to be a good starting-point for discussion between actors by allowing the development of alternative scenarios, which in turn can help building up a shared understanding leading to a shared culture. A set of quantitative indicators is not sufficient to describe the complexity of a situation and can only contribute to the discussion. Topics such as farmers' long-term feed self-sufficiency cannot be captured by a set of quantitative impact indicators alone. Positive impacts on the environment such as decreased pollution has an impact through crop rotations, cannot be reflected by LCA with the current methodological choices of our study. They deserve more qualitative reflection and evaluation. The sharing of knowledge between the actors in value chains is vital for initiating ecological transition in food value chains.

Contributing to the ecological transition of food value chains offers provides the possibility of offering with clearly differentiated criteria. However, the growing interest of the public and consumers in these offers comes with an increase demand for proof of compliance regarding the criteria that differentiate the products. Given the complexity of defining the values and the solutions to be implemented, the collective knowledge of the actors in value chains becomes a real source of added value, as was shown in the founding work of Penrose's resource-based view [71,72]. The development of this knowledge suggests the implementation of real practices of sharing and cooperation between actors. A shared understanding is required for systemic improvements to practices by anticipating the consequences of interventions on complex systems represented by value chains.

This work clearly shows that including economics in a sustainability assessment could be a fundamental error. In fact, the empirical approach has yielded a result that favors animal nutrition involving the purchase of imported raw materials, having traveled through many food miles, such as soybeans from Brazil or USA. However, this type of solution does not correspond to the current expectations of consumers or the public, who have a desire for localness, which has increased following the Covid crisis nor to the imperatives of ecosystem protection imposed by climate change. This does not mean that it is possible to ignore the economic factor, but it seems to us that it must be dealt with in parallel with the redesign project. Defining the upstream of the study on social and environmental performance, the amplitude of possible changes on the economic level 
would make it possible to establish the extent of the transformations that can be envisaged. Selecting the financing options, after the study has been completed, would make it possible to decouple the three types of concerns without naively dismissing the economic dimension, which will in any case be a determining factor in the choice of the actions that will actually be undertaken.

For private actors to meet these demands, more work is needed on the assessment of sustainability through the prism of environmental and social criteria alone, to obtain a clear picture of what the sustainability performance of new solutions is, independently from the economic performance in the sense in which private actors traditionally understand it. This is a difference lying in the degree of ambition or responsibility of the actors, when a choice must be made between weak sustainability measures and strong sustainability measures. One of the distinctions to be made between the two could be the degree of consideration of the strategy and values of organizations. A better shared knowledge through the chain of possible improvement solutions, their evaluation and the individual funding methods that they imply, could help actors to position themselves and especially highlight the image of organizations whose strategies are really the most virtuous.

\section{Conclusions}

This study investigated the potential impact of cooperation in enabling FVC actors to make strategic decisions to redesign their activities to improve sustainability. We investigated (i) whether actors have different weightings for sustainability issues and (ii) whether their priorities allow them to co-construct new solutions that contribute to sustainable value chain transitions. This study revealed that the stakeholders did indeed have different weightings and that this did not prevent them from putting forward two of the same solutions without this leading to effective changes in practices. Our results highlight the importance of cooperation that involves the different actors of the value chains in processes that associate transversal approaches to the value chain and alternately bottom up and top down in order to allow a real enrichment of the problem analysis stage and that of the proposal of new solutions. On the other hand, codecision-making is a complex process because the organizations that make up a value chain have different interests and there is no reason for them to spontaneously move towards the same sustainability strategy or the same evolutionary choices unless they are directed, guided and supported by an authority that provides a framework. The role of public policies, which are empowered to take public expectations into account and mobilize the scientific knowledge produced to document the stakes of ecological transitions, cannot be totally absent from this subject. The choice of issues to focus on for the sustainable transition of food chains cannot be left solely to the choice or expectations of the end consumer in an optimistic vision of the capacities of economic actors to fully grasp societal issues.

Author Contributions: Conceptualization, G.P. and G.Y.-L.B.; methodology, G.P. and Y.L.; software, Y.L.; validation, G.Y.-L.B. and C.E.; formal analysis, G.P. and Y.L.; investigation, G.P.; data curation, G.P. and Y.L.; writing—original draft preparation, G.P.; writing—review and editing, G.P., Y.L., G.Y.L.B. and C.E.; supervision, G.Y.-L.B. and C.E.; project administration, G.Y.-L.B.; funding acquisition, G.Y.-L.B. All authors have read and agreed to the published version of the manuscript.

Funding: This research was funded by AgroParisTech SDSC Chair.

Conflicts of Interest: The authors declare no conflict of interest. 


\section{Appendix A}

\begin{tabular}{|l|llllllllllll|}
\hline (kg, $1000 \mathrm{~kg}$ feed) & A & B & C & D & E & F & G & H & I & J & K & L \\
Barley & 115 & 0 & 0 & 115 & 0 & 0 & 263 & 263 & 0 & 0 & 93 & 93 \\
Wheat & 8 & 0 & 0 & 8 & 0 & 0 & 104 & 104 & 0 & 0 & 606 & 611 \\
Winter barley & 3 & 0 & 0 & 3 & 0 & 0 & 0 & 0 & 0 & 0 & 0 & 0 \\
\hline Triticale & 185 & 0 & 0 & 185 & 0 & 0 & 246 & 246 & 0 & 0 & 0 & 0 \\
\hline Oat & 2 & 0 & 0 & 2 & 0 & 0 & 71 & 71 & 0 & 0 & 0 & 0 \\
Rye & 1 & 0 & 0 & 1 & 0 & 0 & 47 & 47 & 0 & 0 & 0 & 0 \\
\hline Maize & 36 & 350 & 350 & 36 & 350 & 350 & 28 & 28 & 759 & 759 & 0 & 0 \\
\hline Peas & 339 & 339 & 339 & 339 & 339 & 339 & 97 & 97 & 97 & 97 & 0 & 0 \\
Fava beans & 90 & 90 & 90 & 90 & 90 & 90 & 28 & 28 & 28 & 28 & 0 & 0 \\
\hline Lupin & 5 & 5 & 5 & 5 & 5 & 5 & 3 & 3 & 3 & 3 & 0 & 0 \\
Soybeans & 110 & 110 & 110 & 110 & 110 & 110 & 0 & 0 & 0 & 0 & 0 & 0 \\
\hline Sunflower & 0 & 0 & 0 & 0 & 0 & 0 & 8 & 8 & 8 & 8 & 0 & 0 \\
\hline Colza & 33 & 33 & 33 & 33 & 33 & 33 & 0 & 0 & 0 & 0 & 0 & 0 \\
\hline Fodder beets & 16 & 16 & 16 & 16 & 16 & 16 & 0 & 0 & 0 & 0 & 0 & 0 \\
\hline Colza cake & 0 & 0 & 0 & 0 & 0 & 0 & 35 & 35 & 35 & 35 & 100 & 0 \\
\hline Soy cake & 0 & 0 & 0 & 0 & 0 & 0 & 30 & 30 & 30 & 30 & 84 & 116 \\
Sunflower cake & 0 & 0 & 0 & 0 & 0 & 0 & 0 & 0 & 0 & 0 & 0 & 61 \\
\hline Cane molasses & 0 & 0 & 0 & 0 & 0 & 0 & 13 & 13 & 13 & 13 & 38 & 22 \\
\hline Soybean oil & 0 & 0 & 0 & 0 & 0 & 0 & 5 & 5 & 5 & 5 & 13 & 7 \\
\hline Other added minerals & 56 & 56 & 56 & 56 & 56 & 56 & 23 & 23 & 23 & 23 & 65 & 90 \\
\hline
\end{tabular}

Figure A1. Composition of the different feed formulas used in the 12 alternatives.

Table A1. TMeasures of the sustainability indicators for each alternative.

\begin{tabular}{|c|c|c|c|c|c|c|c|c|c|c|c|c|c|c|c|}
\hline & Indicator & Unit & Code & $\mathbf{A}$ & B & C & D & $\mathbf{E}$ & $\mathbf{F}$ & G & $\mathbf{H}$ & $\mathbf{I}$ & $\mathbf{J}$ & $\mathbf{K}$ & L \\
\hline \multirow{9}{*}{ 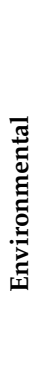 } & Freshw. eutroph. & $\mathrm{kg} \mathrm{SO} 2 \mathrm{eq}$ & Env1 & 0.1 & 0.1 & 0.1 & 0.1 & 0.1 & 0.1 & 0.1 & 0.1 & 0.1 & 0.1 & 0.1 & 0.1 \\
\hline & Terrestrial acidif. & $\mathrm{kg} \mathrm{SO} 2 \mathrm{eq}$ & Env2 & 8 & 7.7 & 7.7 & 8 & 7.7 & 7.7 & 8.5 & 8.5 & 8.9 & 8.9 & 8.2 & 8.3 \\
\hline & Human toxicity & kg 1,4-DB eq & Env3 & 591.4 & 572.5 & 572.5 & 591.4 & 572.5 & 572.5 & 131.6 & 131.6 & 201.2 & 201.2 & 269.8 & 320.6 \\
\hline & Fossil-fuel depletion & $\mathrm{kg}$ oil eq & Env4 & 25.5 & 24.5 & 24.5 & 25.5 & 24.5 & 24.5 & 22.5 & 22.5 & 29.7 & 29.7 & 26.8 & 29.4 \\
\hline & Water depletion & $\mathrm{m}^{3}$ & Env5 & 36.8 & 35.6 & 35.6 & 36.8 & 35.6 & 35.6 & 11.1 & 11.1 & 32 & 32 & 8.3 & 3.9 \\
\hline & Climate change & $\mathrm{kg} \mathrm{CO} 2 \mathrm{eq}$ & Env6 & 200.9 & 178.8 & 178.8 & 200.9 & 178.8 & 178.8 & 191.3 & 191.3 & 195.8 & 195.8 & 180.7 & 207.4 \\
\hline & Land occupation & $\mathrm{m} 2 \mathrm{a}$ & Env7 & 836.5 & 692.6 & 692.6 & 836.5 & 692.6 & 692.6 & 531.1 & 531.1 & 458.1 & 458.1 & 394.8 & 541.6 \\
\hline & Freshwater ecotox. & $\mathrm{kg} \mathrm{1,4-DB} \mathrm{eq}$ & Env8 & 2.2 & 2.3 & 2.3 & 2.2 & 2.3 & 2.3 & 1.6 & 1.6 & 2.4 & 2.4 & 1.4 & 1.2 \\
\hline & Marine ecotox. & $\mathrm{kg} 1,4-\mathrm{DB}$ eq & Env9 & 432.2 & 412.5 & 412.5 & 432.2 & 412.5 & 412.5 & 84.3 & 84.3 & 93.4 & 93.4 & 199.7 & 129.3 \\
\hline \multirow{7}{*}{ 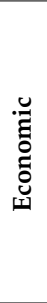 } & Invest. short-term & $€ /$ ton & Eco1 & 21 & 21 & 21 & 27 & 27 & 27 & 15 & 21 & 15 & 21 & 0 & 0 \\
\hline & Invest. mid-term & $€ /$ ton & Eco2 & 14 & 14 & 14 & 18 & 18 & 18 & 10 & 14 & 10 & 14 & 0 & 0 \\
\hline & Invest. long-term & $€ /$ ton & Eco3 & 7 & 7 & 7 & 9 & 9 & 9 & 5 & 7 & 5 & 7 & 0 & 0 \\
\hline & Feed manuf. cost & $€ /$ ton & Eco4 & 30 & 39 & 39 & 30 & 39 & 39 & 31.3 & 31.3 & 38.5 & 38.5 & 0 & 0 \\
\hline & Total feed cost & $€ /$ ton & Eco5 & 267 & 259 & 259 & 267 & 259 & 259 & 260 & 260 & 254 & 254 & 249 & 255 \\
\hline & Waste & $\%$ & Eco6 & 1 & 5 & 5 & 1 & 5 & 5 & 1 & 1 & 5 & 5 & 0 & 0 \\
\hline & Added labor cost & $€ / \mathrm{kg}$ & Eco7 & 3 & 6 & 3 & 3 & 6 & 3 & 9.5 & 3 & 9.5 & 3 & 0 & 0 \\
\hline \multirow{4}{*}{ 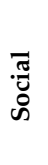 } & Sup. Work hours & $\mathrm{h} /$ day & Soc1 & 0.17 & 0.33 & 0.17 & 0.17 & 0.33 & 0.17 & 0.5 & 0.17 & 0.5 & 0.17 & 0 & 0 \\
\hline & Biodiv. Varieties & \#/formula & Soc2 & 2767 & 1821 & 1821 & 2767 & 1821 & 1821 & 3013 & 3013 & 2067 & 2067 & 1118 & 1102 \\
\hline & Biodiv. Species & \#/formula & Soc3 & 9.67 & 6.33 & 6.33 & 9.67 & 6.33 & 6.33 & 11.3 & 11.3 & 7 & 7 & 6 & 5.33 \\
\hline & Localness (100-) & $\% /$ formula & Soc4 & 84.1 & 65 & 65 & 84.1 & 65 & 65 & 51.5 & 51.5 & 15.1 & 15.1 & 6.5 & 9 \\
\hline
\end{tabular}

\section{References}

1. Neven, D. Developing Sustainable Food Value Chains; FAO: Roma, Italy, 2014; ISBN 9251084815.

2. da Silva, J.G. Future of Food Symposium; Food and Agriculture Organization (FAO): Rome, Italy, 11 June 2019.

3. De Vries, M.; de Boer, I.J.M. Comparing environmental impacts for livestock products: A review of life cycle assessments. Livest. Sci. 2010, 128, 1-11. [CrossRef]

4. Macready, A.L.; Hieke, S.; Klimczuk-Kochańska, M.; Szumiał, S.; Vranken, L.; Grunert, K.G. Consumer trust in the food value chain and its impact on consumer confidence: A model for assessing consumer trust and evidence from a 5-country study in Europe. Food Policy 2020, 92, 101880. [CrossRef]

5. Ahi, P.; Searcy, C. A comparative literature analysis of definitions for green and sustainable supply chain management. J. Clean. Prod. 2013, 52, 329-341. [CrossRef] 
6. Farahani, R.Z.; Rezapour, S.; Drezner, T.; Fallah, S. Competitive supply chain network design: An overview of classifications, models, solution techniques and applications. Omega 2014, 45, 92-118. [CrossRef]

7. Sarkis, J.; Zhu, Q.; Lai, K. An organizational theoretic review of green supply chain management literature. Int. J. Prod. Econ. 2011, 130, 1-15. [CrossRef]

8. Seuring, S.; Sarkis, J.; Müller, M.; Rao, P. Sustainability and supply chain management-An introduction to the special issue. J. Clean. Prod. 2008, 15, 1545-1551. [CrossRef]

9. Zhu, Q.; Sarkis, J. Relationships between operational practices and performance among early adopters of green supply chain management practices in Chinese manufacturing enterprises. J. Oper. Manag. 2004, 22, 265-289. [CrossRef]

10. Harris, G.A.; Componation, P.J.; Farrington, P.A. An exploration of Fisher's framework for the alignment of supply chain strategy with product characteristics. Eng. Manag. J. 2010, 22, 31-43. [CrossRef]

11. de Salins, M.L.; Yannou-Le Bris, G.; Chapdaniel, A. Managing sustainability in supply chains: The sustainable Demand-Supply chain approach, a proposal for a pragmatic approach in the food sector. In Proceedings of the 11th Wageningen International Conference on Chain and Network Management-WICaNeM, Capri, Italy, 4-6 June 2014.

12. Oliva, R.; Watson, N. Cross-functional alignment in supply chain planning: A case study of sales and operations planning. J. Oper. Manag. 2011, 29, 434-448. [CrossRef]

13. Geels, F.W. Technological transitions as evolutionary reconfiguration processes: A multi-level perspective and a case-study. Res. Policy 2002, 31, 1257-1274. [CrossRef]

14. Stuart, D.; Worosz, M.R. Risk, anti-reflexivity, and ethical neutralization in industrial food processing. Agric. Hum. Values 2012, 29, 287-301. [CrossRef]

15. Garcia-Gonzalez, J.; Eakin, H. What can be: Stakeholder perspectives for a sustainable food system. J. Agric. Food Syst. Community Dev. 2019, 8, 61-82. [CrossRef]

16. Marin, A.; Ely, A.; Van Zwanenberg, P. Co-design with aligned and non-aligned knowledge partners: Implications for research and coproduction of sustainable food systems. Curr. Opin. Environ. Sustain. 2016, 20, 93-98. [CrossRef]

17. Seuring, S. A review of modeling approaches for sustainable supply chain management. Decis. Support Syst. 2013, 54, 1513-1520. [CrossRef]

18. Meynard, J.-M.; Jeuffroy, M.-H.; Le Bail, M.; Lefèvre, A.; Magrini, M.-B.; Michon, C. Designing coupled innovations for the sustainability transition of agrifood systems. Agric. Syst. 2017, 157, 330-339. [CrossRef]

19. Holloway, S.S.; Sebastiao, H. The role of business model innovation in the emergence of markets: A missing dimension of entrepreneurial strategy? J. Strategy Innov. Sustain. 2010, 6, 4.

20. Chapman, M.; Klassen, S.; Kreitzman, M.; Semmelink, A.; Sharp, K.; Singh, G.; Chan, K. 5 Key Challenges and Solutions for Governing Complex Adaptive (Food) Systems. Sustainability 2017, 9, 1594. [CrossRef]

21. Hubeau, M.; Marchand, F.; Van Huylenbroeck, G. Sustainability experiments in the agri-food system: Uncovering the factors of new governance and collaboration success. Sustainability 2017, 9, 1027. [CrossRef]

22. Konefal, J. Governing sustainability transitions: Multi-stakeholder initiatives and regime change in United States agriculture. Sustainability 2015, 7, 612-633. [CrossRef]

23. Nchanji, E.B. Sustainable Urban Agriculture in Ghana: What Governance System Works? Sustainability 2017, 9, 2090. [CrossRef]

24. White, D.D.; Jones, J.L.; Maciejewski, R.; Aggarwal, R.; Mascaro, G. Stakeholder analysis for the Food-Energy-Water nexus in Phoenix, Arizona: Implications for nexus governance. Sustainability 2017, 9, 2204. [CrossRef]

25. Blumberg, R.; Leitner, H.; Cadieux, K.V. For food space: Theorizing alternative food networks beyond alterity. J. Polit. Ecol. 2020. [CrossRef]

26. Blok, V.; Gremmen, B.; Wesselink, R. Dealing with the wicked problem of sustainability: The role of individual virtuous competence. Bus. Prof. Ethics J. 2016. [CrossRef]

27. Frame, B. "Wicked","messy", and "clumsy": Long-term frameworks for sustainability. Environ. Plan. C Gov. Policy 2008, 26, 1113-1128. [CrossRef]

28. Peterson, H. Transformational supply chains and the'wicked problem'of sustainability: Aligning knowledge, innovation, entrepreneurship, and leadership. J. Chain Netw. Sci. 2009, 9, 71-82. [CrossRef]

29. Connor, A.N.; Northrop, R.B. Ecological Sustainability: Understanding Complex Issues; CRC Press: Boca Raton, FL, USA, 2016; ISBN 1466565136.

30. Steiner, G.; Posch, A. Higher education for sustainability by means of transdisciplinary case studies: An innovative approach for solving complex, real-world problems. J. Clean. Prod. 2006, 14, 877-890. [CrossRef]

31. Bruinsma, J. World Agriculture: Towards 2015/2030: An FAO Study; Routledge: London, UK, 2017; ISBN 1351536354.

32. Raikes, P.; Friis Jensen, M.; Ponte, S. Global commodity chain analysis and the French filière approach: Comparison and critique. Econ. Soc. 2000, 29, 390-417. [CrossRef]

33. Palpacuer, F. Competence-Based Strategies and Global Production Networks a Discussion of Current Changes and Their Implications for Employment. Compet. Chang. 2000, 4, 353-400. [CrossRef]

34. Walters, D.; Lancaster, G. Implementing value strategy through the value chain. Manag. Decis. 2000. [CrossRef]

35. Rastoin, J.-L.; Ghersi, G. Le Système Alimentaire Mondial. Concepts Méthodes, Analyses et Dynamiques; Quae: Paris, France, 2010. [CrossRef]

36. Gereffi, G.; Humphrey, J.; Sturgeon, T. The governance of global value chains. Rev. Int. Polit. Econ. 2005, 12, 78-104. [CrossRef] 
37. Dapiran, G.P.; Hogarth-Scott, S. Are co-operation and trust being confused with power? An analysis of food retailing in Australia and the UK. Int. J. Retail Distrib. Manag. 2003. [CrossRef]

38. Corstjens, J.; Corstjens, M. Store Wars: The Battle for Mindspace and Shelfspace; Wiley: Chichester, UK, 1995 ; Volume 5.

39. De Chernatony, L. Branding in an era of retailer dominance. Int. J. Advert. 1989, 8, 245-260. [CrossRef]

40. Des Garets, V. Les relations distributeur-fabricant et les modalités de leur coordination. Faire Rech. Logistique Distrib. 2000, 109-126.

41. Filser, M. Canaux de Distribution: Description, Analyse, Gestion; Vuibert: Paris, Franch, 1989; ISBN 2711776441.

42. Fornari, E.; Grandi, S.; Fornari, D. Effects of intra-brand competition between private labels and manufacturer brands: Empirical results from the Italian market. Int. Rev. Retail. Distrib. Consum. Res. 2011, 21, 541-554. [CrossRef]

43. Grant, R.M. Multinationality and performance among British manufacturing companies. J. Int. Bus. Stud. 1987, 18, 79-89. [CrossRef]

44. Zhao, X.; Huo, B.; Flynn, B.B.; Yeung, J.H.Y. The impact of power and relationship commitment on the integration between manufacturers and customers in a supply chain. J. Oper. Manag. 2008, 26, 368-388. [CrossRef]

45. Bloom, P.N.; Perry, V.G. Retailer power and supplier welfare: The case of Wal-Mart. J. Retail. 2001, 77, 379-396. [CrossRef]

46. Yannou-Le Bris, G.; Serhan, H.; Duchaîne, S.; Ferrandi, J.-M.; Trystram, G. Ecodesign and Ecoinnovation in the Food Industries; John Wiley \& Sons: Hoboken, NJ, USA, 2020; ISBN 1786304899.

47. Matopoulos, A.; Vlachopoulou, M.; Manthou, V.; Manos, B. A conceptual framework for supply chain collaboration: Empirical evidence from the agri-food industry. Supply Chain Manag. Int. J. 2007, 12, 177-186. [CrossRef]

48. Gereffi, G.; Korzeniewicz, M. Commodity Chains and Global Capitalism; ABC-CLIO: Santa Barbara, CA, USA, 1994 ; ISBN 0275945731.

49. Porter, M.E. Industry structure and competitive strategy: Keys to profitability. Financ. Anal. J. 1980, 36, 30-41. [CrossRef]

50. Porter, M.E. The five competitive forces that shape strategy. Harv. Bus. Rev. 2008, 86, 78.

51. Petit, G.; Yannou-Le Bris, G.; Trystram, G. Codesign of Sustainable Performance Objectives in Food a Value Chain. In Proceedings of the ICED 2017, Vancouver, BC, Canada, 21-25 August 2017.

52. Herrera-Reyes, A.T.; de los Ríos Carmenado, I.; Martínez-Almela, J. Project-Based Governance Framework for an Agri-Food Cooperative. Sustainability 2018, 10, 1881. [CrossRef]

53. Peterson, H.C.; Wysocki, A.; Harsh, S.B. Strategic choice along the vertical coordination continuum. Int. Food Agribus. Manag. Rev. 2001, 4, 149-166. [CrossRef]

54. Basset-Mens, C.; Van der Werf, H.M.G. Scenario-based environmental assessment of farming systems: The case of pig production in France. Agric. Ecosyst. Environ. 2005, 105, 127-144. [CrossRef]

55. Dourmad, J.-Y.; Ryschawy, J.; Trousson, T.; Bonneau, M.; Gonzàlez, J.; Houwers, H.W.J.; Hviid, M.; Zimmer, C.; Nguyen, T.L.T.; Morgensen, L. Evaluating environmental impacts of contrasting pig farming systems with life cycle assessment. Animal 2014, 8, 2027-2037. [CrossRef]

56. Garcia-Launay, F.; Dusart, L.; Espagnol, S.; Laisse-Redoux, S.; Gaudré, D.; Méda, B.; Wilfart, A. Multiobjective formulation is an effective method to reduce environmental impacts of livestock feeds. Br. J. Nutr. 2018, 120, 1298-1309. [CrossRef]

57. Liu, Y.; Eckert, C.; Yannou-Le Bris, G.; Petit, G. A fuzzy decision tool to evaluate the sustainable performance of suppliers in an agrifood value chain. Comput. Ind. Eng. 2019, 127, 196-212. [CrossRef]

58. Liu, Y.; Eckert, C.M.; Earl, C. Assessing Suppliers for Complex Products from the Perspective of Power. IEEE Trans. Eng. Manag. 2020. [CrossRef]

59. Barbier, E.B. The concept of sustainable economic development. Environ. Conserv. 1987, 14, 101-110. [CrossRef]

60. Petit, G.; Sablayrolles, C.; Yannou-Le Bris, G. Combining eco-social and environmental indicators to assess the sustainability performance of a food value chain: A case study. J. Clean. Prod. 2018. [CrossRef]

61. Öberg, C. The role of business networks for innovation. J. Innov. Knowl. 2019, 4, 124-128. [CrossRef]

62. Uzzi, B. Social structure and competition in interfirm networks: The paradox of embeddedness. Adm. Sci. Q. 1997, 35-67. [CrossRef]

63. Delassus, A. Survey Report: Prepare the Transition to a 100\% Organic Diet in the Pays de la Loire Pig Farms; Nantes, France, 2011. Available online: https:/ / pays-de-la-loire.chambres-agriculture.fr/fileadmin/user_upload/National/FAL_commun/ publications/Pays_de_la_Loire/brochure_12_enquete_rapport_porc_AB.pdf (accessed on 7 June 2021). (In French)

64. Nutrinoë. Comparative Advantage of Feed System in Breton Pig; Rennes, France; Available online: https: / / www.nutrinoe.fr/files / NUTRINOE_Etude.pdf (accessed on 7 June 2021). (In French)

65. Saaty, T.L. The Analytical Hierarchy Process, Planning, Priority. In Resource Allocation; RWS Publications: Pittsburgh, PA, USA, 1980.

66. Yoon, K.P.; Hwang, C.-L. Multiple Attribute Decision Making: An Introduction; Sage Publications: Newbury Park, CA, USA, 1995; Volume 104, ISBN 1452213577.

67. Pickton, D.W.; Wright, S. What's swot in strategic analysis? Strateg. Chang. 1998, 7, 101-109. [CrossRef]

68. GreenFlex/ADEME. Responsible Consumption Barometer; Report 2019; GreenFlex: Paris, France, 2019.

69. Taylor, D.H. Value chain analysis: An approach to supply chain improvement in agri-food chains. Int. J. Phys. Distrib. Logist. Manag. 2005. [CrossRef]

70. Gölgeci, I.; Gligor, D.M.; Tatoglu, E.; Arda, O.A. A relational view of environmental performance: What role do environmental collaboration and cross-functional alignment play? J. Bus Res. 2019, 96, 35-46. [CrossRef] 
71. Penrose, E.T. The Theory of the Growth of the Firm; John Wiley \& Sons Inc.: New York, NY, USA, 1959; Volume 1, pp. 1-23.

72. Eisenhardt, K.M.; Schoonhoven, C.B. Resource-based view of strategic alliance formation: Strategic and social effects in entrepreneurial firms. Organ. Sci. 1996, 7, 136-150. [CrossRef] 